\title{
Taalonderwijs en esthetische ervaring
}

\author{
Ewout van der Knaap: Literatuur en film in het \\ vreemdetalenonderwijs. \\ Bussum: Uitgeverij Coutinho, 2019.
}

De problematiek van taalonderwijs op school wordt tegenwoordig steeds vaker gethematiseerd. Ewout van der Knaap (letterkundige, expert op het gebied van Duitse poëzie en literatuurdidactiek) heeft een diepgaand onderzoek gedaan naar hoe het vreemdetalenonderwijs met behulp van literatuur kan worden ondersteund. De auteur introduceert zijn nieuw verschenen boek Literatuur en film in het vreemdetalenonderwijs in een indrukwekkend filmpje (gemaakt door de Universiteit Utrecht):

Taallessen moeten ergens over gaan, en allerlei vormen van literatuur, dus poëzie, proza en theater en natuurlijk ook film, bieden de inhoud. Talenvakken hebben zoveel meer te bieden dan rijtjes, structuren, oefeningen. Literatuur en film kunnen leerlingen enthousiast maken over de taal en de cultuur, zo ontwikkelen ze de kennis, houding en vaardigheden om met andere culturen om te gaan. ${ }^{1}$

Het nieuwe boek van Van der Knaap werd in mei 2019 gepubliceerd door uitgeverij Countinho, wat geen toeval is omdat Countinho door zijn vakdidactische profiel educatieve leermaterialen en didactische vakboeken publiceert in het Nederlands. De auteur richt zich op het onderwijzen van vreemde talen in het vwo en havo binnen het Nederlandse schoolsysteem. Er worden diverse manieren beschreven waarop docenten literatuur en film in vreemdetalenonderwijs kunnen integreren om enerzijds te breken met het communicatiegerichte taalonderwijs van de afgelopen 20 jaar en 
anderzijds ook andere - waaronder literaire, persoonlijke, morele, culturele, esthetische en socioculturele - competenties naast de verschillende talige vaardigheden (zoals lezen, schrijven, luisteren en spreken) te benadrukken. Dit is een heel belangrijk doel omdat er naast literatuurlessen nauwelijks vakken zijn te vinden die door de bemiddeling van een bepaalde lexicale leerstof, en naast de ontwikkeling van de vier vermelde vaardigheden, aandacht besteden aan de persoonlijke en morele ontwikkeling van leerlingen.

De zeven hoofdstukken van het boek belichten visies op literatuur- en fictieonderwijs, werken aan literaire ontwikkeling, diverse integratiemogelijkheden van literatuur en taalvaardigheden, interculturele benaderingen, doelen en gebruik van film, en de behandeling van de literatuurgeschiedenis en het literaire begrippenapparaat binnen het vreemdetalenonderwijs.

Het boek is goed gestructureerd, de hoofdstukken zijn volgens hetzelfde principe opgebouwd: ze beginnen allemaal met een korte inleiding die door een vragenlijst wordt gevolgd, waar het hoofdstuk zelf het antwoord op geeft. De hoofdstukken worden door talloze figuren en tabellen geillustreerd, wat het leesproces vergemakkelijkt. Het is belangrijk om te benadrukken dat er ook online studiemateriaal bij het boek hoort dat ten eerste aanvullende tips bij literatuuronderwijs biedt en ten tweede nuttige websites en bijlagen bevat die zeer productief kunnen worden ingezet in de klas. Taaldocenten en didactische deskundigen vormen de doelgroep van het boek, maar omwille van zijn karakter kan het ook als leerstof of universitair handboek, en dankzij het online studiemateriaal ook als elearning-cursus in het kader van de lerarenopleiding, gebruikt worden.

Hoewel het boek praktijkgericht is, wordt in de eerste twee hoofdstukken voldoende aandacht besteed aan het presenteren van de theoretische basis van het onderzoeksgebied. In de titel van het eerste hoofdstuk gebruikt de auteur de term "literatuur- en fictieonderwijs". Ondanks de positieve eigenschappen van dit hoofdstuk moet hier vermeld worden dat het onderscheid tussen literatuur en fictie verwarrend werkt: literatuur manifesteert zich per definitie door zijn fictionele karakter - zonder dat zou het moeilijk zijn om over literatuur te spreken. Afgezien daarvan is het hoofdstuk zeer goed gelukt. Het gaat gedetailleerd in op doelen en methoden van literatuur en literaire teksten, de relatie tussen lezen, lezer en literariteit, factoren van literariteit en literaire competenties. De auteur bespreekt hoe deze (bv. talige, esthetische, cognitieve) competenties kunnen worden opgenomen in de taallessen. 


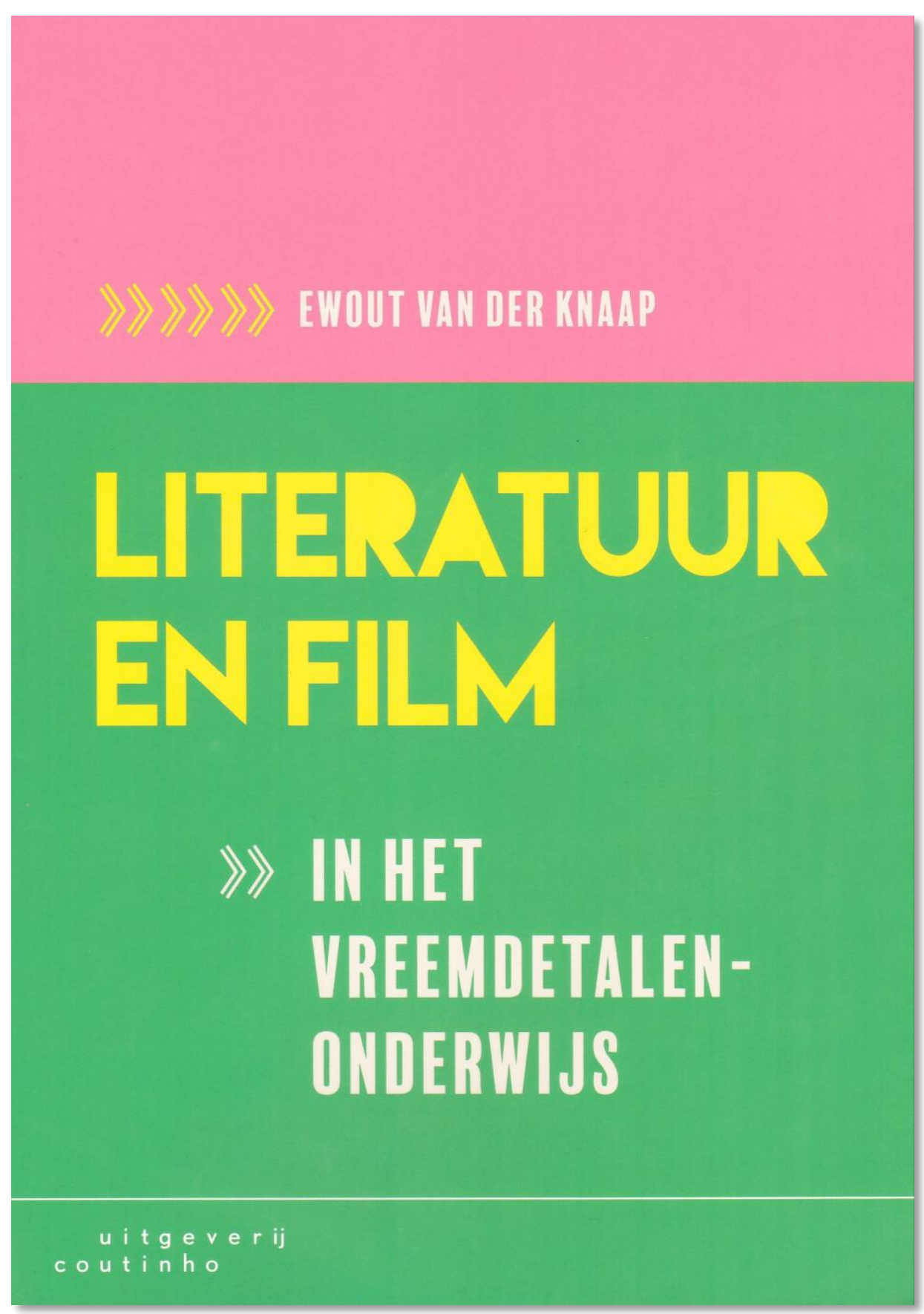


Volgens hem is dit vaak moeilijk te bereiken omdat de voorwaarde van dit soort vakoverstijgend taalonderwijs is dat de leerling al over een zekere leeservaring moet beschikken, zowel in zijn moedertaal als in een vreemde taal. Als dit het geval is, moeten de literaire teksten en de methode heel zorgvuldig worden gekozen zodat ze bij het talige (ERK) niveau van de leerling passen. Om dit te doen, is het essentieel om het doel van de taalles en het doel van de literatuurles apart te verduidelijken. De doelstellingen van taallessen en literatuurlessen bepalen wat voor type docent de les en het vak eisen. Er wordt herhaaldelijk over de leerlinggerichte en de cultuurgerichte docentprofielen in het boek gesproken, waarbij vooral het eerste geschikt lijkt te zijn voor de integratie van literatuuren vreemdetalenonderwijs. Van der Knaap kent verschillende richtingen van de literatuurwetenschap toe aan deze twee docentprofielen. Dientengevolge worden onder meer de literatuurhistorische benaderingen, de feministische of de postkoloniale literatuurkritiek, de receptie-esthetica en de narratologie aan het leerlinggerichte docentprofiel verbonden. Het kan vastgesteld worden dat het boek perfect past bij het internationale taaldidactische discours, rekening houdend met het feit dat de DaF-onderzoeken ook de voorkeur geven aan receptie-esthetica. Hoewel deze richting het belangrijkste wetenschappelijke discours van de jaren ' 70 is, lijkt het didactisch gezien het meest effectief te zijn voor de integratie van taal- en literatuuronderwijs. Deze richting houdt rekening met het effect van de tekst op de lezer, of zelfs de emotionele en cognitieve gehechtheid van de lezer aan de tekst.

Het tweede hoofdstuk gaat, behalve enkele korte theoretische delen, over specifieke methodologische technieken die het nut van verschillende literaire teksten in taallessen laten zien. De belangrijkste vragen in dit hoofdstuk zijn dus: over welke literaire competenties moet een leerling beschikken om literaire teksten in de les te kunnen behandelen? Welke genres zijn geschikt voor de doelgroep? Welke fasen kent het proces van kennismaking met literaire teksten? Wat voor werkvormen zijn geschikt om literaire teksten te kunnen verwerken? Waar moet de docent op letten bij het kiezen van een tekst? Hierop antwoordt de auteur met het niveaumodel van Theo Witte $^{2}$ dat oorspronkelijk voor het onderwijzen van $\mathrm{Ne}$ derlandse literatuur werd uitgewerkt. In dit model zijn zes diverse niveaus onderscheiden waarvan de eerste drie (belevend lezen, herkennend lezen, reflecterend lezen) bij het leerlinggerichte docentprofiel en de laatste drie niveaus (interpreterend lezen, letterkundig lezen en academisch lezen) bij het cultuurgerichte docentprofiel aansluiten. Van der Knaap wijst erop dat 
de literaire competenties van leerlingen in het vwo het vierde niveau moeten bereiken. De niveaus hierboven vergen naast een grotere literaire en esthetische ervaring ook een talig niveau $\mathrm{C} 1$ dat vooral in het hoger onderwijs verwacht kan worden. Het hoofdstuk biedt ook een aantal praktische tips voor zijn lezer over het gebruik van de verschillende literaire genres (gedichten, aforismen, korte verhalen, sprookjes, drama's, adolescentenromans, beeldverhalen, graphic novels) in het vreemdetalenonderwijs. Naast werkvormen worden ook teksten in vier talen (Engels, Duits, Frans en Spaans) geboden die heel nuttig kunnen zijn voor de docenten bij het kiezen van geschikte teksten die aansluiten bij het niveau van de doelgroep.

Het derde hoofdstuk voldoet maximaal aan de verwachtingen van lezers die door concrete werkvormen en voorbeelden willen zien hoe literatuur kan worden betrokken bij het proces van het ontwikkelen van verschillende taalvaardigheden. De auteur benadrukt echter dat het naast het taalonderwijs de moeite waard is aandacht te besteden zowel aan de literaire en fictionele inhoud als aan de esthetische vorm. In dit verband worden verscheidene werkvormen gepresenteerd van het niveau A1 tot $\mathrm{C} 1$. Het boek is heel professioneel geschreven, hoewel er in dit hoofdstuk enkele tekortkomingen zijn: er zijn minder opdrachten op A1-niveau beschikbaar. Hoewel de auteur meer werkvormen presenteert die volgens hem voor alle niveaus geschikt zijn, is dit in enkele gevallen twijfelachtig. Het zou bijvoorbeeld heel uitdagend zijn voor leerlingen op niveau A1 om een leesdagboek te schrijven of om een tekst of een fragment van een tekst in een andere tekstsoort te herschrijven in een vreemde taal waarmee ze net zijn begonnen. Afgezien daarvan is de 'voorbeeldbibliotheek' uiterst nuttig en kan die enorme hulp bieden in het werk van een taaldocent.

In hoofdstuk vier benadrukt de auteur dat taalonderwijs m.b.v. literatuur en fictie rekening moet houden met de ontwikkeling van socioculturele competenties naast de taalvaardigheden van leerlingen. Interculturele literatuur is hier zeker geschikt om de leerlingen vertrouwd te maken met verschijnselen als het vreemde, discriminatie, racisme, empathie, enz. De inzet van interculturele literatuur in de taalles lijkt duidelijk vruchtbaar te zijn.

Het volgende hoofdstuk van het boek bespreekt het nut van films in het vreemdetalenonderwijs. Hoewel de bruikbaarheid van film ook in de titel van het boek staat, schrijft de auteur daar wat korter over. Van der Knaap gaat dieper in op de competenties die met behulp van film kunnen worden ontwikkeld. Hier kan de lezer opmerken dat dit medium best wel complex 
is en vrij veel ontwikkelingsmogelijkheden biedt: naast het ontwikkelen van luistervaardigheid (door het beluisteren van de film) en leesvaardigheid (door ondertitels), worden bij de leerling ook andere competenties gestimuleerd, bijvoorbeeld interculturele, filmesthetische of verhaalanalytische competenties. Natuurlijk moet bij het selecteren van films ook rekening worden gehouden met de talige en filmesthetische ervaringen van de leerlingen. Met de filmdidactische introductie van Van der Knaap en de talrijke praktische werkvormen kunnen de docenten innovatieve taallessen plannen waarbij de leerlingen zeker gemotiveerd raken.

In de laatste twee hoofdstukken behandelt Van der Knaap de koppeling van literatuurgeschiedenis en terminologie aan het vreemetalenonderwijs. Van der Knaap belicht dat deze onderwerpen op grond van Witte's model uitsluitend vanaf het niveau 4 mogelijk zijn. De behandeling van literatuurgeschiedenis is echter duidelijk gebonden aan niveau $\mathrm{C} 1$ waar we misschien niet meer de uitdagingen van de taaldocent maar die van de literatuurdocent tegenkomen.

Samenvattend heeft de lezer met dit werk een boek in handen dat - ondanks de zeer weinige hierboven genoemde tekortkomingen - heel goed gestructureerd, stevig doordacht, en theoretisch behoorlijk gefundeerd is, en dat zowel door taaldocenten als door didactici kan worden gebruikt. Van der Knaap eindigt zijn boek waar het werk van een taaldocent ook eindigt: bij methodologische kwesties van literatuuronderwijs in vreemde talen op een hoog niveau, omdat het daar niet zozeer om een vakoverstijgende taalles gaat, maar om vakoverstijgend literatuuronderwijs, waar dan weer een ander boek aan kan worden besteed. De lezer kan alleen maar hopen dat het volgende boek van Van der Knaap het antwoord zal geven op de vraag hoe literatuurwetenschap, literatuurgeschiedenis en literatuurtheorie kunnen worden gehanteerd in een groep met anderstaligen.

\section{Noten}

1 https://www.youtube.com/watch?v=wn_4NdY4i7c\&feature=emb_title (Geraadpleegd op 29.01.2020.)

2 Zie meer: Witte, Het oog van de meester. 


\section{Bibliografie}

Witte, Theo, 2008. Het oog van de meester: een onderzoek naar de literaire ontwikkeling van havo-en vwo-leerlingen in de tweede fase van het voortgezet onderwijs. Delft: Eburon.

\section{Internetbronnen}

https://www.youtube.com/watch?v=wn_4NdY4i7c\&feature=emb_title (Geraadpleegd op 29.01.2020.) 